\title{
Bioaccumulation and translocation factors of petroleum hydrocarbons in Aeluropus littoralis
}

\author{
Mohammad Rafiee ${ }^{1}$, Mahsa Jahangiri Rad ${ }^{2}$, Arash Afshari ${ }^{3}$ \\ ${ }^{1}$ Assistant Professor of Environmental Health Engineering, Department of Environmental Health, School of Public Health, Shahid \\ Beheshti University of Medical Sciences, Tehran, Iran \\ ${ }^{2}$ Assistant Professor of Environmental Health Engineering, Department of Environmental Health Engineering, Tehran Medical \\ Sciences Branch, Islamic Azad University, Tehran, Iran \\ 3. MSc Student of Environmental Engineering, Department of Environmental Engineering, Tehran Shomal Branch, Islamic Azad \\ University, Tehran, Iran
}

\begin{abstract}
Background: Polycyclic aromatic hydrocarbons (PAHs), which consist of fused conjugated aromatic rings, not only are toxic to humans and other living organisms, but will also pollute groundwater These compounds can be point source or non-point source and are one of the most widespread organic pollutants. Some of them are suspected carcinogens and are linked to other health problems. This study was carried out to assess the petroleum hydrocarbon phytoremediation potential of the Aeluropus littoralis species. Accumulation of PAHs in roots and upper parts of A. littoralis has been determined. Translocation factor (TF) was also calculated.

Methods: In this study, soil samples were taken from the vicinity of Isfahan oil refinery, and the PAHs compounds were analyzed with gas chromatography. One-meter soil columns were prepared from the control and contaminated soil. Unplanted A. littoralis treatments were also prepared to eliminate the effects of environmental factors on the reduction of oil-based contaminants. Seventeen weeks after planting, soil columns were sampled at $25,50,75$, and $100 \mathrm{~cm}$ depths, and the concentration of petroleum hydrocarbons and number of oil-degrading bacteria were counted. Moreover, the roots and shoots of $A$. littoralis were separated and weighed.

Results: Results indicated that $A$. littoralis reduced the concentration of petroleum hydrocarbons to a significantly higher extent than the control treatment. Increasing depth was associated with improved petroleum hydrocarbon concentrations and decreased number of oil-degrading bacteria. Mostly, the bioaccumulation factor (BAF) of PAHs was $<1$, which shows A. littoralis could be an excluder of PAHs. The results also showed that the TF of PAHs was less than one, and hence, $A$. littoralis could be considered as an accumulator of PAHs.

Conclusion: It can be concluded that this species is suitable for use in the phytoremediation of PAHS contamination. For further confirmation, an evaluation under field conditions should be undertaken. Keywords: Biodegradation, Soil, Polycyclic aromatic hydrocarbons, Aeluropus littoralis plant Citation: Rafiee M, Jahangiri Rad M, Afshari A. Bioaccumulation and translocation factors of petroleum hydrocarbons in Aeluropus littoralis. Environmental Health Engineering and Management Journal 2017; 4(3): 131-136. doi: 10.15171/EHEM.2017.18.
\end{abstract}

Article History:

Received: 22 December 2016 Accepted: 19 February 2017 ePublished: 20 March 2017

\section{Introduction}

Petroleum is a compound consisting of hundreds of organic and trace amounts of inorganic substances. Although each organic compound has unique physical and chemical properties, they are often divided into the paraffin, naphthenes, and aromatic hydrocarbons (1). Some of the most problematic organic components in crude oil are the polycyclic aromatic hydrocarbons (PAHs). Their bioaccumulation, airborne transportation, and persistence in the environment are of great concern since PAHs have been identified as carcinogens, mutagens, and teratogens (2). Various methods have been applied to clean up oil contaminated soil, including chemical, biological, and physical methods (3). Phytoremediation is a relatively new method that relies on the use of plants to remove a wide range of contaminants without the need to excavate the contaminant material. It has gained special attention over the past 20 years because plants have an extraordinary capacity to clean up the environment (4). Plants not only clean up contaminants, they also slow groundwater hydraulics and reduce the spread of pollutants. Each plant affects the rate of degradation diversely (5). The plant's ability to degrade the compound, the lethal dosage, rate of degradation, and type of plant should be considered when phytoremediation is applied. The type of soil with which the oil has contact also affects 
how well the oil is degraded. It has been shown that soils higher in organic matter actually reduce the rate of oil decay (6). There are also studies to suggest that the type of soil affects the rate of degradation. Soils containing larger pores are capable of breaking down hydrocarbons faster since the oil can percolate through the soil at a faster rate (7). Phytoremediation as applied to petroleum clean-up in salt marshes has received great attention owing to its low cost and low environmental impacts. Six ways are known as the predominant processes for contamination cleanup by phytoremediation, including rhizodegradation, phytoextraction, phytovolatilization, phytodegradation, rhizofiltration, and rhizostabilization (4). The first and most important method of petroleum hydrocarbon removal is rhizodegradation, a process which occurs in the rhizosphere (8). Research has shown that the larger the microbial population is, the faster the rate of degradation will be (9). In the rhizosphere, petroleum compounds can be degraded to simpler, less toxic molecules or mineralized entirely to water and carbon dioxide. The rhizosphere also removes harmful petroleum hydrocarbons from soil and water by promoting volatilization through transpiration and by accumulating organic compounds through lignification (10).

Various plant species have been proven capable of remediating petroleum-contaminated soils in bench-top studies, including Vicia faba, Zea mays, Triticum aestivum $\mathrm{L}$, and Glycine max $(11,12)$. Aeluropus littoralis from the Poaceae family is characterized by its high tolerance to soluble salts and can be grown in saline habitats. A. littoralis exhibits a rapid growth rate, high biomass production, and widespread root system distribution in saline and non-saline soils (13). In a research conducted by Rezvani et al, A. littoralis showed a high capability in cadmium and lead removal from contaminated soils (14). The present study was therefore designed to investigate the bioaccumulation and translocation characteristics of A. littoralis in hydrocarbon removal from contaminated soil around the Isfahan Oil Refinery (Isfahan, Iran).

\section{Materials and methods}

\section{Selection of soil sampling}

The Isfahan Oil Refinery selected for this study is located about $340 \mathrm{~km}$ south of Tehran. It is Iran's second-largest refinery with a production capacity of 265000 bpd (Figure $1)$. The city is located on the main north-south and eastwest routes crossing Iran $\left(32^{\circ} 38^{\prime} \mathrm{N} 51^{\circ} 39^{\prime} \mathrm{E}\right)$. It has an arid climate and is situated at $1590 \mathrm{~m}(5217 \mathrm{ft})$ above sea level on the eastern side of the Zagros Mountains (15). The refinery, established in 1976, receives its crude oil feedstock from the Maroon and Shadegan fields. Esfahan's products include liquid petroleum gas (LPG), gasoline, light naphtha, light jet fuel, ATK, petrochemical feedstock, kerosene, gas oil, lube oil, fuel oil, and asphalt. Soil samples were taken from land near the refinery's Sulfur Recovery Unit. Control samples were also chosen from uncontaminated nearby land. Considering the size of the area $\left(1000 \mathrm{~m}^{2}\right), 5$ locations were selected out of every 200 square meters of land. At each location, $2 \mathrm{~kg}$ of soil was sampled from $30 \mathrm{~cm}$ below the surface in 5 geographical directions; the samples were mixed to form a compound sample of about $10 \mathrm{~kg}$. Finally, three subsamples were drawn from each compound sample and stored at a controlled temperature $\left(4^{\circ} \mathrm{C}\right)$ before being analyzed.

Measuring physical and chemical properties of soil Physical and chemical properties of soil play significant roles in the efficacy of processes reducing petroleum hydrocarbons (16). In this study, soil samples were air dried and passed through a 2-mm sieve. Soil texture (through hydrometry), $\mathrm{pH}$, electrical conductivity, organic matter, total nitrogen, available phosphorus, and potassium content of each sample were determined according to EPA methods $9071 \mathrm{~A}$ and $3540 \mathrm{~B}$ (17).

Determination of total petroleum hydrocarbons $\mathrm{PAH}_{\mathrm{s}}$ and total petroleum hydrocarbons (TPHs) in the soil were measured by Soxhlet extraction using a 1:1 (v/v) $\mathrm{n}$-hexane/dichloromethane solvent $(150 \mathrm{~mL})$ mixture for 24 hours. The extracted compounds were then evaporated and condensed using a rotary evaporator under vacuum conditions. Column chromatography (using silica gel and alumina as absorbent) was employed to purify the samples $(18,19)$. The concentration of PAHs in soil was determined with gas chromatography (17).

Phytoremediation procedure Selected for the phytoremediation experiments was $A$.

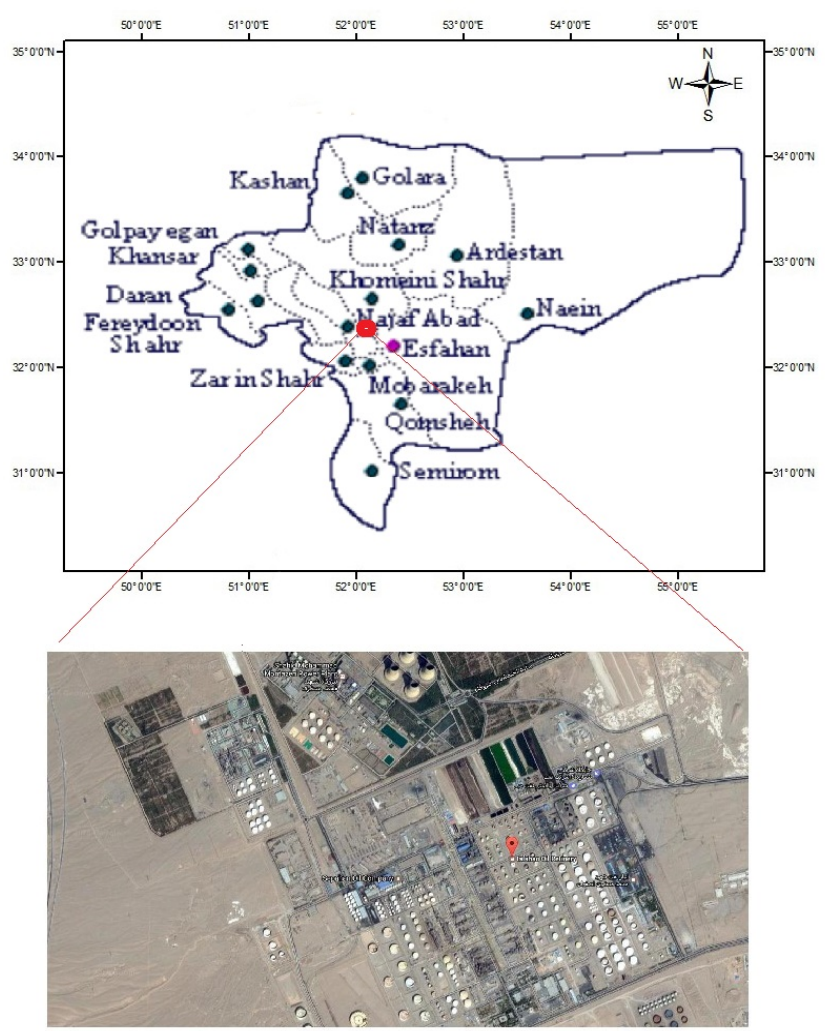

Figure 1. A map location of Isfahan province and Isfahan oil refinery that selected in this research work. 
littoralis, a permanent plant regrowing from underground parts. Polyvinyl chloride (PVC) pipes $(20 \mathrm{~cm}$ in diameter and $100 \mathrm{~cm}$ long) were employed. The pipes were holed at 20,40 , and $60 \mathrm{~cm}$ for the final sampling with $10-\mathrm{cm}$ drainage at the bottom. Considering the density of soil $\left(2.5 \mathrm{~g} / \mathrm{cm}^{3}\right)$ and volume of PVC pipes, the required amount of contaminated soil for each pot was calculated. Phytoremediation experiments were conducted on 3 conditions: 1) TPH removal in the presence of A. littoralis, 2) treatments without plants intended to eliminate the effects of environmental factors on the reduction of oilbased contaminants for each column, and 3) controlled soil samples (without TPH contamination). The experiment pots were filled with the specified amount of either contaminated or control soil samples while $10 \mathrm{~cm}$ empty space was left on top. The TPH concentration in each column was measured as 50000, 55000, 57000, and $60000 \mathrm{ppm}$, respectively. Three repetitions of 4 treatments were conducted on a total of 12 soil columns. The cultured, contaminated, and control soil columns were treated with A. Littoralis seed placed $2 \mathrm{~cm}$ below the top soil ( 3 of them remained untreated to exclude the environmental factors on oil reduction). Thirteen weeks after planting, soil columns were sampled at depths of 20,40 , and $60 \mathrm{~cm}$ and concentrations of petroleum hydrocarbons were analyzed. Finally, the roots and shoots of the plants were separated, dried in an oven at $80^{\circ} \mathrm{C}$ for 48 hours, and weighed.

\section{Plant analysis}

Samples were taken from the plant shoots and roots and analyzed for PAH 11, 12, 13, 14, 15, 16, and 17 weeks after planting. At each stage, plant samples were washed thoroughly with distilled water and oven dried at $70^{\circ} \mathrm{C}$ for 24 hours for further analyses. Plant samples were then ground and digested overnight in a $5-\mathrm{mL}$ acid mixture of $\mathrm{HClO}_{4}$ (Merck) (60\%) and $\mathrm{HNO}_{3}$. Digestion was completed by gradually increasing the temperature from $60^{\circ} \mathrm{C}$ to $195^{\circ} \mathrm{C}\left(60^{\circ} \mathrm{C}, 3\right.$ hours; $100^{\circ} \mathrm{C}, 1$ hour; $120^{\circ} \mathrm{C}, 1$ hour; $150^{\circ} \mathrm{C}, 30$ minutes; $175^{\circ} \mathrm{C}, 30$ minutes; $195^{\circ} \mathrm{C}, 2.5$ hours). After cooling, $\mathrm{HCl}(20 \%, 2.5 \mathrm{~mL})$ was added, and the mixture was whirl-mixed and warmed to $80^{\circ} \mathrm{C}$ for 30 minutes. The final volume was brought to $10 \mathrm{~mL}$ with double-distilled water and rewarmed to $80^{\circ} \mathrm{C}$ for another 30 minutes. Samples were filtered through a cellulose filter $(0.2 \mu \mathrm{M})$. The $\mathrm{PAH}_{\mathrm{s}}$ concentrations in plants were determined using gas chromatography (17-19).

\section{Counting oil-degrading bacteria}

In order to count oil degrading bacteria, one-gram soil samples from the microplots were aseptically collected and transported in sterile containers and on ice to the laboratory. A series of dilutions $\left(10^{-1}-10^{-8}\right)$ were prepared, and total bacterial numbers were determined using a culture medium which consisted of $990 \mathrm{~mL}$ sterile agar solution and $\mathrm{CaCl}_{2} \mathrm{H}_{2} \mathrm{O}$ (0.02), $\mathrm{FeCl}_{3}(0.05)$, $\mathrm{MgSO}_{4-} 7 \mathrm{H}_{2} \mathrm{O}(0.2), \mathrm{K}_{2} \mathrm{HPO}_{4}(1), \mathrm{NH}_{4} \mathrm{NO}_{3}(1), \mathrm{KH}_{2} \mathrm{PO}_{4}$ (1) $(\mathrm{pH}=7)(20)$.
Translocation and bioaccumulation factors

Oil translocation from shoot to root was measured by $\mathrm{T}_{\mathrm{F}}$ which is given below $(18,19)$ :

$T_{f}=\frac{C_{\text {shoot }}}{C_{\text {root }}}$

where $\mathrm{C}_{\text {shoot }}$ and $\mathrm{C}_{\text {root }}$ are oil concentrations in the shoot $\left(\mathrm{mg} \mathrm{kg}^{-1}\right)$ and root of plant $\left(\mathrm{mg} \mathrm{kg}^{-1}\right)$, respectively. $\mathrm{T}_{\mathrm{F}}>1$ indicates that translocation of oil is mostly due to the shoot from the root. ${ }^{7}$ Bioaccumulation factor (BAF) was calculated as follows:

$B A F_{f}=\frac{C_{\text {root }}}{C_{\text {soil }}}$

where $\mathrm{C}_{\text {root }}$ and $\mathrm{C}_{\text {soil }}$ are oil concentrations in the plant root $\left(\mathrm{mg} \mathrm{kg}^{-1}\right)$ and soil $\left(\mathrm{mg} \mathrm{kg}^{-1}\right)$, respectively.

$\mathrm{BAF}>1$ and $\mathrm{BAF}<1$ represent accumulatory and excludery properties.

\section{Results}

Physical and chemical properties of contaminated and control soils are summarized in Table 1.

The results of this experiment showed that soil contaminated with oils has a lower $\mathrm{pH}$ compared to the control soil. Table 2 shows the fraction concentration of each PAHs measured in nearby soil. The mean petroleum hydrocarbon concentration of $65000 \mathrm{mg} / \mathrm{kg}$ suggested that the soil from areas near the oil refinery is extremely contaminated.

Statistical analyses of the main and interaction effects of soil and plants on shoot and root dry matter yield (Figures

Table 1. Physical and chemical properties of soil in the selected area

\begin{tabular}{lcc}
\hline Characteristic & Control soil & Contaminated soil \\
\hline Texture & Sandy clay loam & Sandy clay loam \\
$\mathrm{pH}(1: 2.5)$ & 7.5 & 7.1 \\
$\mathrm{EC}(\mathrm{ds} / \mathrm{m})$ & 2 & 3.5 \\
Organic matter $(\%)$ & 0.5 & 5.2 \\
Total nitrogen $(\%)$ & 0.07 & 0.90 \\
Available phosphorus $(\mathrm{mg} / \mathrm{kg})$ & 36 & 80 \\
Available potassium $(\mathrm{mg} / \mathrm{kg})$ & 15 & 21 \\
\hline
\end{tabular}

Table 2. Concentrations of the measured polycyclic aromatic hydrocarbons and total petroleum hydrocarbons in contaminated soil

\begin{tabular}{lc}
\hline PAHs & Concentration $(\mathrm{mg} / \mathrm{kg})$ \\
\hline Phenantherene & 31 \\
Naphthalene & 40 \\
Fluoranthene & 21 \\
Pyrene & 16 \\
Anthracene & 7.3 \\
Benzo[k]fluoranthene & 0.3 \\
Benzo[a]pyrene & 0.6 \\
TPHs & 65000 \\
\hline
\end{tabular}

Abbreviations: TPHs, total petroleum hydrocarbons; PAHs, polycyclic aromatic hydrocarbons. 
2 and 3) of $A$. littoralis revealed that plant type and soil influence dry matter yield. In fact, dry weight comparisons between the contaminated and control treatments showed reductions of about $22 \%$ and $51 \%$ in root and shoot dry matter of $A$. littoralis in petroleum hydrocarboncontaining soil, respectively.

Shoot and root weights were drastically reduced with increases in oil concentration $(P<0.05)$. In fact, dry weight comparisons between contaminated and control treatments indicated reductions of about $10 \%$ and $20 \%$ in the root and shoot dry matter of A. littoralis in petroleum hydrocarbon-containing soil, respectively.

The effects of depth on petroleum hydrocarbon concentrations and number of oil-degrading bacteria in A. littoralis treatments and control soils at three different depths (Figure 4) were determined. Apparently, the lowest concentration of petroleum hydrocarbons and greatest number of oil-degrading bacteria were observed at 0-20 $\mathrm{cm}$ depth. The comparison of means showed a significant difference between unplanted and planted treatments in terms of petroleum hydrocarbon concentration and number of oil-degrading bacteria $(P<0.05)$ (Table 3 and Figure 4).

The BAFs of PAH (initial concentration of $50000 \mathrm{ppm}$ ) for A. littoralis samples in different weeks (from 1 to 7 ) of growth are given in Figure 5. The BAF represents the contaminant concentration in plants compared with the environment concentration (in soil) (20). TF was calculated to determine the translocation of PAHs from soil to root or from root to upper parts of plants. TF indicates the ability of plants to accumulate PAHs from soils. The calculated TF values are shown in Figure 5.

\section{Discussion}

The results of soil property analyses are consistent with those of other studies and suggest that organic acid production rooting from microorganisms' activity in soil coupled with the presence of sulfur and sulfur oxides in waste oil are responsible for $\mathrm{pH}$ reduction $(16,21)$. On the question of electrical conductivity, this study

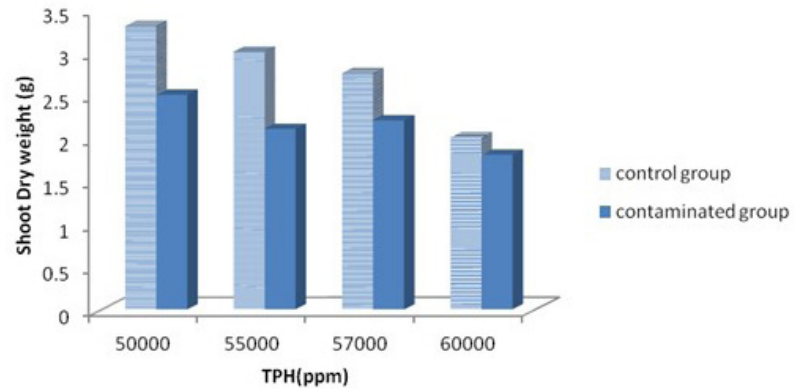

Figure 2. Shoot dry weight of Aeluropus littoralis in the contaminated and control treatments.

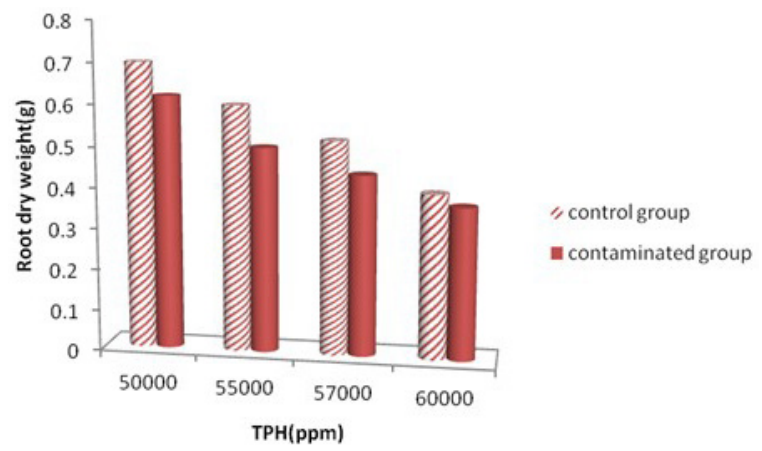

Figure 3. Root dry weight of Aeluropus littoralis in the contaminated and control treatments.

Table 3. Comparison of mean values of percentage reductions in petroleum hydrocarbons and number of oil-degrading bacteria

\begin{tabular}{lcc}
\hline & $\begin{array}{c}\text { Number of oil- } \\
\text { degrading bacteria }\end{array}$ & $\begin{array}{c}\text { Percentage reductions in } \\
\text { petroleum hydrocarbons }\end{array}$ \\
\hline A. littoralis & 600000 & 55 \\
Unplanted & 460000 & 31 \\
\hline
\end{tabular}

found that soils rich in oil showed higher EC. A possible explanation for this might be the presence of metal cations (e.g., nickel and vanadium) in waste oil. The findings of the current study are consistent with those of other researchers who found elevated electrical conductivity

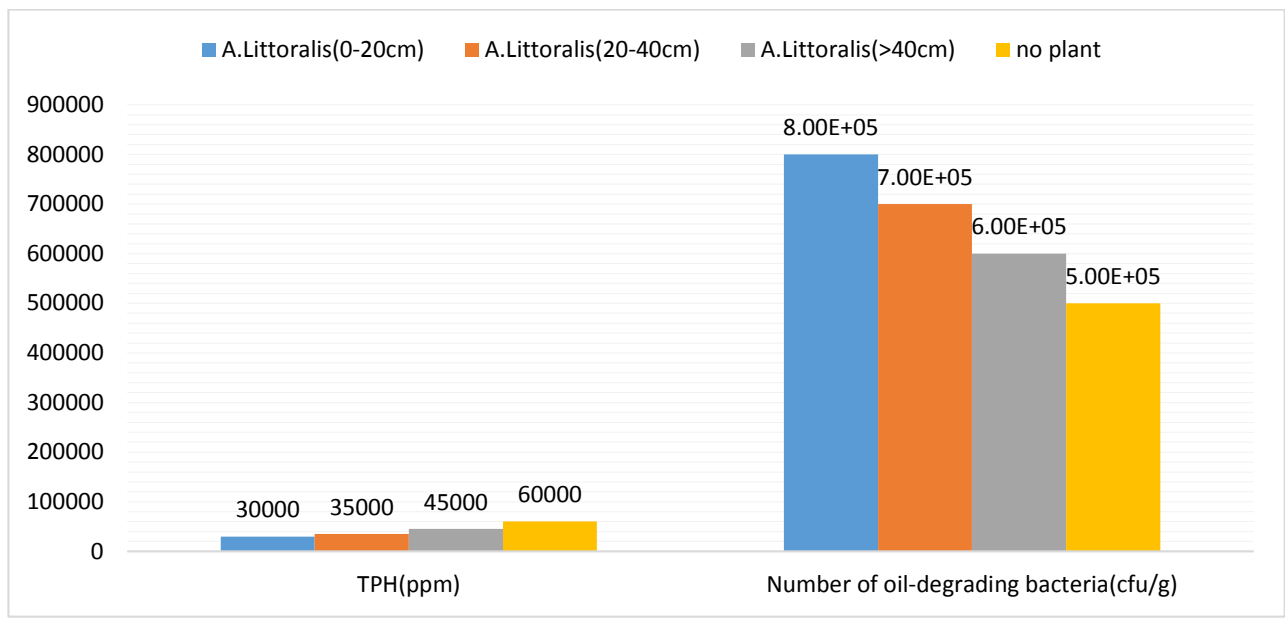

Figure 4. Changes in the concentration of total petroleum hydrocarbons and number of oil-degrading bacteria at different depths of soil. 


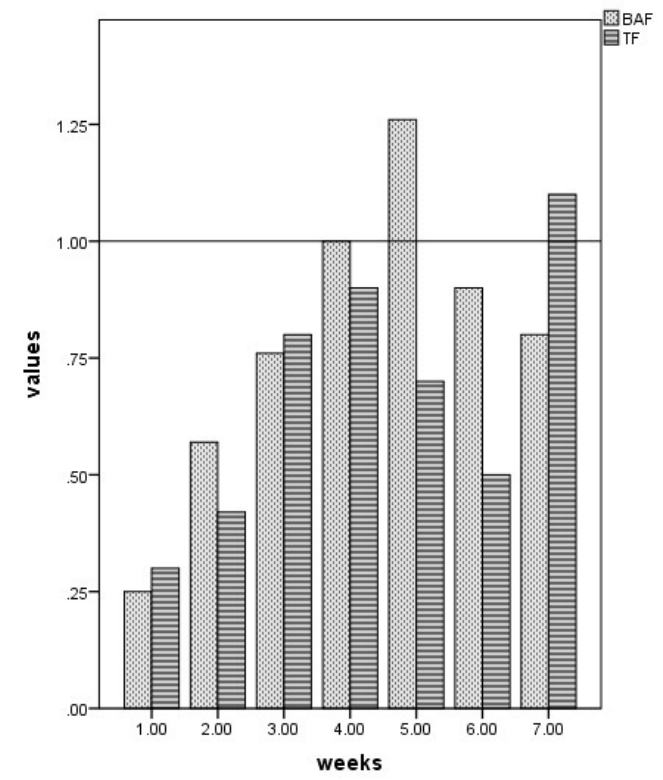

Figure 5. Root dry weight of Aeluropus littoralis in the contaminated and control treatments.

in soils contaminated with petroleum hydrocarbons (22). Another finding was that crude oil degradation in soil increased the organic matter percentage and organic carbon content of the contaminated soil compared to the control soil. These conditions, in turn, led to a decrease in the oxygen content of the contaminated soil and the formation of anaerobic environments which significantly restrict biodegradation. As shown in Figures 2 and 3, the dry matter weights of shoots and roots decreased as compared to control groups $(23,24)$. The effects of depth on petroleum hydrocarbon concentrations and number of oil-degrading bacteria in treatments at three different depths were evaluated. Clearly, the lowest concentration of petroleum hydrocarbons and greatest number of oildegrading bacteria were observed at $0-25 \mathrm{~cm}$ depth. Phytoremediation is responsive to a variety of organic and inorganic compounds. In fact, plants are capable of enhancing the degradation of organic pollutants by releasing nutrients and secretions in soil, transporting oxygen to the root zone, and stimulating and increasing the activity of oil-degrading microbial populations (25). It is encouraging to compare this figure with that found by $\mathrm{Xu}$ et al who explained that the presence of plant roots at this depth explains this finding $(26,27)$. At $20-40 \mathrm{~cm}$ depths, the planted and control treatments were still different, since plant roots can reach this depth. However, higher concentrations of petroleum hydrocarbons and lower numbers of oil-degrading bacteria were detected compared to $0-20 \mathrm{~cm}$ depths.

The findings regarding reductions in dry matter yields support previous research which links the reduction of root and shoot dry matter yield to higher concentrations of PCB $(23,24)$. The BAFs which exhibited concentrations of $\mathrm{PAH}$ in the shoots of $A$. littoralis divided by their values in soil ranged from 0.25 to 1.25 , indicating the accumulation behavior of this plant. The minimum values for accumulation in root samples were observed in five of the seven weeks. BAF values higher than 1 indicate that the plant is highly efficient in removing contaminants from soil. The main tasks of the root include fixing in soil and absorbing water and dissolved compounds (25).

The root contributes to the metabolism of A. littoralis, feeding the whole plant, and often serves to store materials. The ability of roots to accumulate PAH is considered to be a way in which the aerial parts of the plant are protected. In the current experiment, BAF of PAH ranged between 0.25 and 1.3 , suggesting a moderate performance by $A$. littoralis in the phytoremediation of PAH-contaminated soil. Translocation factors (TFs), presented in Figure 5 , ranged from 0.3 to 1.1. As shown, in most cases, the $\mathrm{PAH}$ is uniformly distributed in root parts of A. littoralis, because the value of TF is less than 1 . This indicates that A. littoralis was unable to translocate PAH from the roots to the shoots. Baker reported that plants are classified as accumulators if the heavy metal concentration ratio (shoot to root) is more than one and as excluders if this ratio is less than one (28). Substances that have a high solubility in water are not easily absorbed by plant roots (29). Due to their low solubility in water, hydrophobic chemicals are not easily absorbed in plant roots or remain around the roots. As a result they cannot be translocated into the plant (30).

\section{Conclusion}

The current study used $A$. littoralis to remediate petroleum hydrocarbon-contaminated soil from lands near the Isfahan Oil Refinery. The results showed that A. littoralis is capable of tolerating high concentrations of petroleum hydrocarbons and toxic materials in soil. A. littoralis successfully decreased the concentration of petroleum hydrocarbons in soil. Reductions in contaminants of unplanted soil might be attributed to leaching, adsorption, oxidation in exposure to light, evaporation, or biodegradation. The mechanisms by which plants escalate pollutant removal are different, comprising uptake and concentration, transformation, stabilization and rhizosphere degradation in which plants advance the growth of bacteria in the root zone. At depths of $20-40 \mathrm{~cm}$ and more than $40 \mathrm{~cm}$ where $A$. littoralis roots cannot penetrate, TPH removal decreased. The results of this study indicate that, in all 3 treatments, the maximum concentrations of petroleum hydrocarbons and minimum numbers of oil-degrading bacteria were observed at depths of $60 \mathrm{~cm}$ and more. The number of oil-degrading bacteria in $0-40 \mathrm{~cm}$ depths (with root penetration) was actually twice that in $60 \mathrm{~cm}$ depths (without root penetration).

\section{Acknowledgments}

This study was part of an MS project conducted in the laboratory of the Tehran Medical Sciences Branch of the Islamic Azad University. The authors extend their thanks to all the people who provided help, especially the laboratory staff. 


\section{Ethical issues}

The authors confirm that this paper is the original work of the authors. This manuscript has not been published elsewhere.

\section{Competing interests}

The authors declare that they have no conflicts of interest.

\section{Authors' contributions}

Concept and design of experiments: AF. Performance of experiments: AF. Analysis of data: MJR. Manuscript preparation: MR and MJR.

\section{References}

1. U.S. Environmental Protection Agency (U.S. EPA) Hazard Characterization Document. Screening-Level Hazard Characterization. Washington, DC: EPA; 2011.

2. Kalf DF, Crommentuijn T, van de Plassche EJ. Environmental quality objectives for 10 polycyclic aromatic hydrocarbons (PAHs). Ecotoxicol Environ Saf 1997; 36(1): 89-97. doi: 10.1006/eesa.1996.1495.

3. United States Environmental Protection Agency (EPA). Oil Spill Response Techniques. Available from: https://www. epa.gov/emergency-response/epas-response-techniques. Accessed Nov 17, 2016.

4. Pilon-Smits E. Phytoremediation. Annu Rev Plant Biol 2005; 56: 15-39. doi: 10.1146/annurev.arplant.56.032604.144214.

5. Reilley KA, Banks MK, Schwab AP. Dissipation of Polycyclic Aromatic Hydrocarbons in the Rhizosphere. J Environ Qual 1996; 25(2): 212-9. doi: 10.2134/ jeq1996.00472425002500020002x.

6. Dowty RA. Wetland restoration: the bioremediation of small-scale oil spills in fresh marsh environments and adventitious rooting response in marsh vegetation [dissertation]. Hammond, LA: Masters thesis, Southeastern Louisiana University; 1998.

7. Fayiga AQ, Ma LQ. Using phosphate rock to immobilize metals in soils and increase arsenic uptake in Pteris vittata. Sci Total Environ 2006; 359(1-3): 17-25. doi: 10.1016/j. scitotenv.2005.06.001.

8. Rovira AD. Plant Root Exudates. Botanical Review 1969; 35(1): 35-57. doi: 10.1007/BF02859887.

9. Günther T, Dornberger U, Fritsche W. Effects of ryegrass on biodegradation of hydrocarbons in soil. Chemosphere 1996; 33(2): 203-15. doi: 10.1016/0045-6535(96)00164-6.

10. Kathi S, Khan AB. Phytoremediation approaches to PAH contaminated soil. Indian J Sci Technol 2011; 4(1): 56-63.

11. Diab EA. Phytoremediation of oil contaminated desert soil using the rhizosphere effects of some plants. Res J Agric Biol Sci 2008; 4(6): 604-610.

12. Njoku KL, Akinola MO, Oboh BO. Phytoremediation of crude oil contaminated soil: the effect of growth of glycine max on the physicochemistryand crude oil contents of soil. Nature and Science 2009; 7(10): 79-87.

13. Shahin Kaleybar B, Nematzadeh G, Askari H, Hashemi HR, Kabirnataj S. Physiological and genetic responses of halophyte Aeluropus to salinity. Journal of Crop Breeding 2014;5(12):15-28.

14. Rezvani M, Zaefarian F, Miransari M, Nematzadeh GA. Uptake and translocation of cadmium and nutrients by Aeluropus littoralis. Arch Agron Soil Sci 2012; 58(12):141325. doi: 10.1080/03650340.2011.591385.
15. Assari A, Mahesh TM. Demographic comparative in heritage texture of Isfahan city. Journal of Geography and Regional Planning 2011; 4(8): 463-70.

16. Tang J, Lu X, Sun Q, Zhu W. Aging effect of petroleum hydrocarbons in soil under different attenuation conditions. Agric Ecosyst Environ 2012; 149: 109-117. doi: 10.1016/j. agee.2011.12.020.

17. US Environmental Protection Agency (US EPA). EPA Quality Manual For Environmental Programs. Washington, DC: EPA; 1994.

18. Wuana RA, Okieimen FE, Imborvungu JA. Removal of heavy metals from contaminated soil using chelating organic acids. Int J Environ Sci Technol (Tehran) 2010; 7(3): 485-96. doi: 10.1007/BF03326158.

19. Sleegers F. Phytoremediation as green infrastructure and a landscape of experiences. Proceedings of the Annual International Conference on Soils, Sediments, Water and Energy. Available from: http://scholarworks.umass.edu/ soilsproceedings/vol15/iss1/13.

20. Scragg A. Environmental Biotechnology. New York: Oxford University Press; 2005.

21. Spinelli LF, Schnaid F, Selbach PA, Bento FM, Oliveira JR. Enhancing bioremediation of diesel oil and gasoline in soil amended with an agroindustry sludge. J Air Waste Manag Assoc 2005; 55(4): 421-9. doi: $10.1080 / 10473289.2005 .10464639$.

22. Haines JR, Wrenn BA, Holder EL, Strohmeier KL, Herrington RT, Venosa AD. Measurement of hydrocarbon-degrading microbial populations by a 96 -well most-probable-number procedure. J Ind Microbiol 1999; 16(1): 36-41.

23. Wrenn BA, Venosa AD. Selective enumeration of aromatic and aliphatic hydrocarbon degrading bacteria by a mostprobable-number procedure. Can J Microbiol 1996; 42(3): 252-8.

24. Passatore L, Rossetti S, Juwarkar AA, Massacci A. Phytoremediation and bioremediation of polychlorinated biphenyls (PCBs): state of knowledge and research perspectives. J Hazard Mater 2014; 278: 189-202. doi: 10.1016/j.jhazmat.2014.05.051.

25. TRIPOD. Bioremediation. Available from: http:// bioremediationstudy.tripod.com/id8.html. Accessed Nov 25, 2016.

26. Xu L, Teng Y, Li Z, Norton JM, Luo YM. Enhanced removal of polychlorinated biphenyls from alfalfa rhizosphere soil in a field study: the impact of a rhizobial inoculum. Sci Total Environ 2010; 408(5): 1007-13. doi: 10.1016/j. scitotenv.2009.11.031.

27. Zuberer DA. Recovery and enumeration of viable bacteria. In: Weaver RW, ed. Methods of Soil Analysis, Part 2. Microbiological and Biochemical Properties. Madison, USA: Soil Science Society of America; 1994.

28. Baker AJM. Accumulators and excluders strategies in the response of plants to heavy metals. J Plant Nutr 1981; 3(14): 643-54. doi: 10.1080/01904168109362867.

29. Schnoor JL, Licht LA, McCutcheon SC, Wolfe NL, Carreira LH. Phytoremediation of organic and nutrient contaminants. Environ Sci Technol 1995; 29 (7): 318-23. doi: 10.1021/es00007a747.

30. Schwab AP, Banks MK, Arunachalam M. Biodegradation of polycyclic aromatic hydrocarbons in rhizosphere soil. In: Hinchee RE, Anderson DB, Hoeppel RE, eds. Bioremediation of Recalcitrant Organics. Columbus: Battelle Press; 1995. 